\title{
HABITAT SELECTION BY GRAZING ANIMALS IN HETEROGENEOUS ENVIRONMENTS: THE CASE OF HILL SHEEP IN WESTERN IRELAND
}

Bryony Williams (Corresponding author; e-mail: bryony.williams@ gmail.com), Teagasc Research Centre, Mellows Campus, Athenry, Co. Galway, Ireland; and Applied Ecology Unit, Centre for Environmental Science, National University of Ireland, Galway, Ireland; Sean Walls, Anatrack Ltd, 52 Furzebrook Road, Wareham, Dorset, BH20 5AX, UK; Michael Walsh, Teagasc Research Centre, Mellows Campus, Athenry, Co. Galway, Ireland; Mike Gormally, Applied Ecology Unit, Centre for Environmental Science, National University of Ireland, Galway, Ireland.

Cite as follows: Williams, B., Walls, S., Walsh, M. and Gormally, M 2012 Habitat selection by grazing animals in heterogeneous environments: the case of hill sheep in western Ireland. Biology and Environment: Proceedings of the Royal Irish Academy 2012. DOI: $10.3318 /$ BIOE.2012.16.

Received 3 August 2011. Accepted 19 December 2011. Published 30 June 2012.

\section{Bryony Williams, Sean Walls, Michael Walsh and Mike Gormally}

\author{
ABSTRACT
}

\begin{abstract}
Uplands and peatlands are of high conservation importance and, while grazing animals are a key management tool for conservation, grazing-related damage can easily occur. Damage to European uplands is most notable in Britain and Ireland, where Scottish Blackface is the dominant hill sheep breed. Therefore, if conservation strategies that address concerns of grazing-related damage are to be strengthened, the Scottish Blackface is a good subject and a better understanding of their resource use would be advantageous. While previous habitat selection studies of hill sheep have depended on direct observation, this particular study uses Global Positioning System tracking collars to determine ewe locations. The study site is on a mountainside in western Ireland that is dominated by blanket bog $(52.8 \%)$ and wet heath $(35.3 \%)$. Habitat mapping and ewe range and resource selection analyses indicated that habitat selection was significant $(P<0.05)$, typically acid grassland is selected most followed by wet heath, with blanket bog habitats selected least. Seasonal variation in habitat selection was also evident. These results (1) corroborate the findings of previous work elsewhere on plant community/habitat selection and (2) provide additional information that can be used to strengthen existing or new hill grazing management models that are used to aid decision-making. In particular, management plans should take into consideration the availability (both in terms of total area and connectivity) of the preferred sheep habitats and specifically consider grazing pressure in and between those habitats.
\end{abstract}

\section{INTRODUCTION}

Irish and British uplands and peatlands are typically dominated by heathland and/or blanket bog habitats. They are included in Annex I of the European Habitats Directive and are considered to be of international importance (European Commission 2008). Heathland landscapes are reported to be best represented in the UK and Ireland (Thompson et al. 1995). Eight per cent of the world's blanket bog occurs in Ireland (Department of Arts Heritage Gaeltacht and the Islands 2002) and Britain supports $10 \%-14 \%$ of the world's blanket bog (Cadbury 1987).

While grazing animals are widely recognized as an important management tool for habitats of conservation importance, grazing-related damage to European uplands is most notable in the UK and Ireland (European Environmental Advisory Councils 1999). Grazing-related damage has been attributed to rural development schemes in the past, for example, the 'Ewe Premium' in Ireland, that led to a rise in stocking levels (Bleasdale and Sheehy Skeffington 1992). Although there has since been a general reduction in stocking rates as a result of agri-environmental policy (Holden et al. 2007), damage is still evident, particularly in localized areas. Drought, wind, rain, frost, soil type and topography can contribute to vegetation loss, exposure of bare ground and soil erosion (Fenton 1937) but clearly inappropriate management of grazing animals (particularly overstocking) can facilitate the erosion process through defoliation and trampling (Brigand and Bioret 1994).

The frequency, intensity and timing of grazing can be controlled where domestic animals are grazed. However, choosing appropriate management regimes, including suitable stocking rates, is problematic and site specific because of the many influencing variables. For example, between animal, breed, site and season differences are reported in diet selection (Fraser et al. 2009), resulting in differences in grazer impact on vegetation. Tools for making management decisions at site level include vegetation condition assessments, calculations for sustainable stocking rates (Dúchas the Heritage Service and the Department of Agriculture and Food 1999; National Parks and Wildlife Service 
2005) and computer-based hill grazing management models (Armstrong et al. 1997; Macaulay Institute 2009).

Many government agri-environment schemes have been criticized for simply using stocking rate as the management criteria but there is obviously a need for more detailed management prescriptions based on grazer behaviour (Hester and Baillie 1998). A better understanding of grazer behaviour should facilitate resolution of concerns regarding grazing-related damage to habitats of conservation importance.

It seems reasonable to expect a link between habitat selection, that is, where grazers choose to spend time, and grazing-related damage. Habitat selection by wild animals has previously been studied comprehensively for a number of animals of direct conservation concern (Manly et al. 1993), compared with relatively few studies of habitat selection by domestic grazing animals. A study by Hunter (1962) investigated sheep selection of heath and grassland plant communities using direct observations, the findings of which were used in one of the main examples of a grazing management model (Armstrong et al. 1997). Additional information on diet and habitat selection by hill sheep reported by others was obtained from plot-based trials, sites with two available habitats, faecal analysis and/or field observations of sheep, impacted vegetation or faecal deposition density (Hewson and Wilson 1979; Welch 1984; Grant et al. 1985; Clarke et al. 1995; Hester and Baillie 1998; Hester et al. 1999; Fraser et al. 2009). Compared with detailed plant community mapping or alternative diet selection research methods, the less intensive, broader level of habitat mapping is more accessible to field workers and faster to carry out over large areas (Nature Conservancy Council 1990). Thus, ranking habitat use relative to availability can be an effective tool for predicting sheep distribution trends and ecological consequences.

Plant characteristics, such as species identity, height, structure, palatability and digestibility, influence diet selection (e.g. Heady 1964; Agreil et al. 2005; Ginane and Dumont 2006). Therefore, plant characteristics, along with grazer preferences, are often included in grazing management models that predict impacts of grazing management on flora and fauna (e.g. Thomson and Simpson 2006; Macaulay Institute 2009). Management models have become a powerful decision-making tool, synthesizing current knowledge and experience, and need sufficient data for validation (Wallis De Vries and van de Koppel 1998). Further information on habitat selection by grazing animals on sites with different habitat assemblages and environmental factors will improve these models.
Resource selection analysis compares resource use with that available. Global Positioning System (GPS) collars offer an efficient method for collecting data on resource use by animals (Hulbert and French 2001; Davidson-Watts et al. 2006; Thomas et al. 2008). GPS collars have recently been used to investigate habitat selection by lowland sheep on shrubby rangeland in Argentina (Bertiller and Ares 2008) and grassland in Germany (Putfarken et al. 2008). Locations of hill sheep have previously been tracked using GPS devices to investigate accuracy of GPS data, home ranges, circadian rhythm and bite rates and classification of behaviour categories (Roberts et al. 1995; Rutter et al. 1997; Hulbert et al. 1998; Hulbert and French 2001; Umstätter et al. 2008) but not habitat selection. Compared with field observations and manual mapping techniques, advantages of current GPS tracking techniques include minimizing human disturbance, higher recording frequencies and numbers of records, increased location accuracy, superior recording success rates (i.e. when study animals are obscured from surveyors' view) and absence of recorder bias (Hulbert and French 2001).

These advantages of GPS collars make possible the collection of data for more detailed research on habitat selection in spatially heterogeneous environments, which is urgently needed if grazer distribution and, therefore, impact are to be reliably predicted (Wallis De Vries and van de Koppel 1998). Habitat selection, by hill sheep with access to a mosaic of upland and peatland habitats, was investigated using GPS tracking collars. Scottish Blackface is the dominant hill sheep breed in Ireland and Britain and is, therefore, an excellent subject for investigating resource use by grazers with the aim of providing knowledge for improving conservation strategies that address concerns of grazing-related damage. The specific objectives of this study were to (1) estimate the habitat content of the study area, (2) test whether habitat use by hill sheep was non-random, (3) compare diurnalnocturnal and seasonal habitat selection and (4) make recommendations for the conservation management of upland and peatland habitats based on our findings.

\section{MATERIALS AND METHODS}

\section{STUDY AREA}

The study area consisted of 217ha of upland and peatland ecosystems at the Teagasc Hill Sheep Farm in County Mayo, Ireland $\left(53^{\circ} 37^{\prime} \mathrm{N}, 09^{\circ} 41^{\prime} \mathrm{W}\right)$ (Fig. 1). The farm is located within the catchment area of the Erriff River and part of the Mweelrea/ Sheeffry/Erriff Complex candidate Special Area for Conservation and proposed Natural Heritage Area 


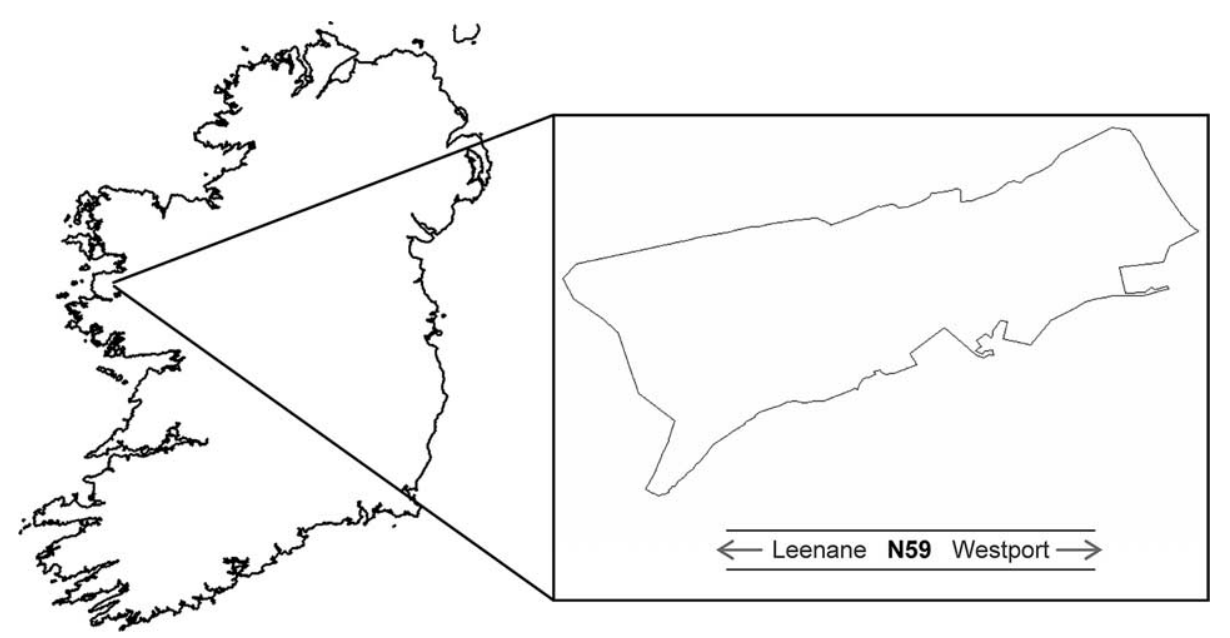

Fig. 1-Location of the study area in Co. Mayo, Ireland.

(National Parks and Wildlife Service 2010). This Complex contains habitats listed under Annex I of the European Habitats Directive including blanket bogs, northern Atlantic wet heaths with Erica tetralix and depressions on peat substrates of the Rhynchosporion (European Commission 2008).

The Hill Sheep Farm is on the southsoutheasterly slopes of Ben Gorm and ranges in altitude from $15 \mathrm{~m}$ to $275 \mathrm{~m}$ OD. The site is Class 5 for agricultural land use (i.e. has low agricultural productivity potential, Gardiner and Radford 1980). The soils are peats (55\%), lithosols (34\%) which are mainly organic, and mineral soils which consist of humic/peaty podzols and gleys (11\%). Peat depth ranges between $30 \mathrm{~cm}$ and $525 \mathrm{~cm}$ (Walsh et al. 2000).

A maritime temperate climate prevails with the nearest synoptic meteorological station located in Belmullet, Co. Mayo, approximately $70 \mathrm{~km}$ distant (Met Éireann). Based on a 30-year average (1961-1990), the mean daily temperature was $14.0^{\circ} \mathrm{C}$ in July and $5.7^{\circ} \mathrm{C}$ in January, and the annual mean daily duration of bright sunshine was $3.5 \mathrm{~h}$ at Belmullet (Met Éireann 2010). The mean annual rainfall recorded on-site (1993-2005) was $2086.4 \mathrm{~mm}$ (L. O'Malley, pers. comm.). The minimum and maximum hours of daylight at the study area were calculated as $7 \mathrm{~h} 27 \mathrm{~min}$ and $17 \mathrm{~h} 4 \mathrm{~min}$, based on the latitude and longitude co-ordinates and GPS tracking dates (Met Éireann, pers. comm.).

Scottish Blackface sheep grazed the study area at stocking rates of 0.4 ewes/ha in spring (March-May), 0.9 ewes/ha in summer (JuneAugust) and autumn (September-November) and 0.8 ewes/ha in winter (December-February). These calculations were based on 2004-2005 averages and omitted lambs but included hoggets at a ratio of three hoggets to two ewes. The study area was grazed for 348 days in 2004 and 351 days in 2005. Supplementary feed was not given in the study area. Ewes lambed in early April with a productivity of approximately 1.0 lamb/ewe (based on mean data 2004-2006). Approximately 80 females were retained annually as replacements (L. O’Malley, pers. comm.).

\section{HABITAT SURVEY}

Habitats were mapped using the standard UK and Irish habitat classifications and mapping guidelines (Nature Conservancy Council 1990; Fossitt 2000; Heritage Council 2002). Classes are very similar between the two classifications and both were used to enable comparison with other studies, increase replicability and further applications (such as incorporation into management models). As per the guidelines, habitat patches $\geq 0.25$ ha were mapped in the field with the aid of colour, ortho-corrected aerial photographs taken in 2000 (Ordnance Survey Ireland, Dublin, Ireland). Patches $<0.25$ ha were incorporated into the surrounding, larger habitat patch. Surveys were carried out at a scale of 1:5000. The habitat map was digitized using Geographical Information System (GIS) software (ArcGIS Desktop, V.9.1, ESRI, Redlands, CA, USA) and later exported to range analysis software for comparison with ewe location data (more details below).

\section{TRACKING EWES}

Four Scottish Blackface ewes (core ewes) plus seven substitutes, all two years old, were selected at random at the start of the study (Table 1). Random selection was made by generating random numbers in Excel from the ewe tag numbers list. The age group was selected because it had experience of the study area and was likely to survive for the duration of the $2 \frac{1 / 4}{4}$-year study. Substitute ewes were tracked 
Table 1-Matrix showing '(ewe range number), number of days, number of locations' by ewe and tracking period post-processing for the Complete dataset. Ewes 1-4 are the core ewes tracked when possible and the most stable ewe range for each of the eleven individuals is indicated by bold text (i.e. these are the eleven 'core ranges'). A GPS collar failed to record on one occasion (ewe range no. 0), and one collar was switched from an individual (ewe range no. 19) mid-way through a tracking period (when the ewe became unavailable pre-lambing) and fitted on a replacement ewe (ewe range no. 18).

\begin{tabular}{|c|c|c|c|c|c|c|c|c|c|c|}
\hline $\begin{array}{l}\text { Tracking } \\
\text { period }\end{array}$ & 1 & 2 & 3 & 4 & 5 & 6 & 7 & 8 & 9 & $\begin{array}{l}\text { Total number } \\
\text { of valid ranges }\end{array}$ \\
\hline Season & Spring & Summer & Autumn & Winter & Spring & Summer & Autumn & Winter & Spring & \\
\hline Year & 2004 & 2004 & 2004 & $2004-2005$ & 2005 & 2005 & 2005 & $2005-2006$ & 2006 & \\
\hline \multicolumn{11}{|l|}{ Ewe no. } \\
\hline 1 & & (4) 32,3565 & (8) 31,2782 & (12) 32, 3609 & & (21) 33,3840 & (25) 32, 2559 & (29) 19,2742 & (33) 13,581 & 7 \\
\hline 2 & & (5) 15,1834 & (9) 15,1905 & (13) 14,1413 & (16) 15,1755 & (22) 15,1862 & (26) 14,1848 & (30) 14,1895 & & 7 \\
\hline 3 & & (6) 20,2592 & (10) 20,2492 & (14) 16,1954 & (17) 17,1726 & (23) 20,2545 & (27) 17,1988 & (31) 19,2511 & & 7 \\
\hline 4 & & (7) 24,2534 & (11) 31,3678 & (15) 32,3475 & & (24) 33,4057 & (28) 31,3860 & (32) 29, 779 & & 6 \\
\hline 5 & (0) 0,0 & & & & (18) 6, 700 & & & & (34) 18,2267 & 2 \\
\hline 6 & (1) 10,1076 & & & & & & & & & 1 \\
\hline 7 & (2) 11,1401 & & & & & & & & $(35) 6,150$ & 2 \\
\hline 8 & (3) 27,3152 & & & & & & & & & 1 \\
\hline 9 & & & & & (19) 18,1825 & & & & & 1 \\
\hline 10 & & & & & (20) 24, 2419 & & & & & 1 \\
\hline 11 & & & & & & & & & (36) 31,2607 & 1 \\
\hline $\begin{array}{l}\text { Total no. of } \\
\text { valid ranges }\end{array}$ & 3 & 4 & 4 & 4 & 5 & 4 & 4 & 4 & 4 & 36 \\
\hline
\end{tabular}


only if core ewes became unavailable for tracking on the open hill area in late pregnancy either because they were of low body condition or were twin-bearing. Four ewes were tracked in each of nine season-based tracking periods (each of $\leq 5$ weeks duration) between February 2004 and April 2006, producing a total of 36 ewe ranges. A 'ewe range' is the collection of location data for an individual in any one tracking period. Simultaneous flock observations for $58 \%$ of ewe ranges or $64 \%$ of individuals (Williams et al. 2010) indicated no unusual social behaviour by collared ewes. However, one core ewe was a member of a small social group that chose to repeatedly jump a sheep fence (P.J. Hastings, pers. comm.) to occupy a fenced exclosure which was under a different grazing regime to that of the study area (removed from analyses as explained below).

GPS collars (GPS 2200, Lotek Wireless, Ontario, Canada) weighing $720 \mathrm{~g}$ were used to track ewes. The collars were programmed to record locations at $10-\mathrm{min}$ intervals using scheduling software (GPSHOST, Lotek Engineering, Ontario, Canada), loaded with current satellite almanac files from Lotek and initialized at a known reference point on the farm each time before use. Locations were stored onboard the collar and retrieved after five weeks. This was the maximum time taken for recordings to cease, either through battery pack expiry or data storage capacity (5028 differential locations) being reached (Lotek Wireless 2004).

GPS location data were downloaded to a PC and corrected to increase accuracy using postdifferential correction software (N4, V.1.2138, Lotek Engineering, Ontario, Canada) and files from the nearest active base station $54 \mathrm{~km}$ distant (NUI Galway Base Station, Ordnance Survey Ireland 2012). Post-differentially corrected GPS data had an accuracy of approximately $7 \mathrm{~m}$ radius (Lotek Wireless 2000). This was consistent with our findings in that a very small number of locations fell just outside the stockproof fence $(<7 \mathrm{~m})$ where sheep did not have access. Locations with a position dilution of precision value of more than ten were excluded to further increase accuracy without excessive loss of GPS data (Lotek Wireless 2001; D'Eon and Delparte 2005).

\section{DATA ANALYSIS}

Data processing

Typically in wildlife tracking studies, animals are caught, tagged and released within their home range (Kenward 2001). However in this domestic tracking study, the flock was brought in from the study area, the collars were fitted to selected ewes in an adjacent yard and then sheep were released from the yard and left to make their own way back to their chosen areas. To explore habitats selected by sheep (rather than habitats they had to explore before settling) and filter out data directly influenced by handling, data from the first three days after release were excluded. This period represents the longest time taken by an individual, two days $23 \mathrm{~h}$, rounded to three days, to reach its preferred area. It was chosen objectively by identifying core areas as 95\% cores from inflections on cluster polygon incremental analysis plots (Kenward et al. 2001) and scrutinizing location data against 95\% polygons to identify the time taken for sheep to leave the yard, reach a $95 \%$ polygon and stay there for longer than an overnight stop (taken as $11 \mathrm{~h} 51 \mathrm{~min}$, the annual mean non-daylight hours) en route. The remaining useable data for the eleven core ewe ranges (one per individual tracked, the four core ewes and seven substitutes as explained below) varied from 10 to 33 days and from 1076 to 3840 locations (Table 1), depending on battery life, GPS fix success and animal husbandry practices. A dataset ('Complete'), which consisted of all locations for each ewe range minus the three days post-release, was compiled to assess the ranking of habitat selection. Datasets were also subdivided into Diurnal and Nocturnal datasets based on mean sunrise and sunset times for each ewe range.

Two datasets, 'Stable' and 'Fixed-time' (including diurnal and nocturnal subdivisions) were prepared from the same original 'Complete' dataset. 'Stable' contained the same number of locations per ewe range (based on incremental analysis and representing where ewes settled for the longest time period; the minimum number of locations (253) on the widest incremental analysis plot plateau for each ewe range was applied to all ewe ranges). 'Fixed-time' contained all locations for a fixed time period (i.e. we selected the minimum number of days (10) from each ewe range). The purpose of this process was to overcome problems of inconsistencies between ewe ranges (i.e. a different number of locations recorded and the number of days spanned). Although this resulted in substantial location data omission, there were no or only slight differences in habitat rank sequences between corresponding tests for all three datasets (i.e. Complete, Stable and Fixed-time datasets), including diurnal and nocturnal subdivisions, and overall conclusions remained unchanged. Therefore, habitat selection findings for the Complete dataset (including diurnal and nocturnal subdivisions) only are presented.

\section{Spatial and temporal autocorrelation of data}

Location data from the same individual are not independent data. Therefore tests for resource selection were based on summary statistics (e.g. the proportion of fixes in each habitat category) 
of habitat use from the individual (Kenward 1992; 2001). Of the 36 ewe ranges, eleven individuals were tracked and consequently eleven ewe ranges (one per individual) were potentially suitable for compositional analysis. Ewe range selection was made objectively, regardless of season, based on Minimum Convex Polygon (MCP) incremental analysis which is indicative of range stability (Kenward 2001), that is, ranges where ewes were most settled were selected. Two of the ewes (ewe no. 2 and 9, Table 1) were omitted. Ewe no. 2 chose to occupy a fenced exclosure outside the study area that was under a different management regime, resulting in an invalid ewe range (ewe range no. 13). Two of the ewe ranges (no. 19 and 20) were non-independent (Jacob's index was 0.769 based on geometric mean distances between same-time locations) based on dynamic interaction analysis (Kenward 2001), therefore ewe no. 9, which had the less stable of the two ewe ranges (ewe range no. 19) was omitted. The final sample size was nine because data that breached analysis assumptions of data independence or misrepresented typical habitat availability to the flock were rigorously omitted. Sample sizes for seasonal tests differ and are explained below.

\section{Range and habitat analysis}

The habitat map and tracked ewe location data were imported into range analysis software (Ranges 7, Anatrack Ltd, Dorset, UK). Resource selection by animals is defined as resources used more frequently than expected by chance relative to resource availability (Johnson 1980). Therefore, habitat analyses were performed to estimate (1) the habitat content of the study area, (2) habitat content of ewe ranges and (3) habitat use at location. The boundary of the study area, that is, the area available to animals, was determined by a stockproof fence in this instance. MCPs were produced, which are widely used as a broad estimate of animal ranges and are created by linking the outermost locations (e.g. Aebischer et al. 1993).

\section{Statistical analysis}

Habitat selection was examined using weighted compositional analysis (Compos Analysis V.6.2+, Smith Ecology Ltd, Abergavenny, UK). This allows comparison of both multiple individuals and habitats in the same test (Aebischer et al. 1993). Each individual was weighted by the number of useable locations from the respective tracking period. Proportions of habitat use were compared with those available, using Wilks' lambda $(\Lambda)$ test (multivariate analysis of variance; MANOVA). Based on the selection levels identified by Johnson (1980), analyses were carried out at two selection levels (Fig. 2):
(1) broad, comparing proportions of habitats present within ewe ranges with those available in the study area accessible to sheep, and

(2) detailed, comparing proportions of habitats used at location with those available within individual ewe ranges.

It is unlikely that habitat use and available percentage data follow a multivariate normal distribution, hence randomization tests were used to evaluate the significance of $\Lambda$ and $t$ values (Aebischer et al. 1993). Compositional analysis can only compare habitats with sufficient use/availability to determine a selection pattern; habitats where individuals were rarely recorded may need to be omitted as too many zero values prohibit analysis (Smith 2006). To overcome this issue, we needed to omit the least visited habitats from some analyses and, particularly as the habitat(s) with zero values differed between ewe ranges, we also explored merging similar habitats into groups (refer to the Results section).

\section{Seasonal habitat selection analysis}

Habitat selection analyses were conducted for each of the four seasons using 28 ewe ranges (seasonal datasets, Table 2). Similar to the previous ewe range selection, six of the original 36 ewe ranges were omitted because the same ewe (no. 2, Table 1) repeatedly occupied an area outside the study area (ewe range nos 5, 9, 16, 22, 26 and 30), and two further ewe ranges were omitted as dynamic interaction analyses indicated that data (three pairs consisting of ewe range nos 16, 17 and 20, Table 1) were not independent (Jacob's index >0.75). The ewe ranges of individuals tracked in more than one season were suitable for separate seasonal tests, however, ewe ranges were also included where the same individual was tracked for the same season for more than one sampling year as independence could not be tested.

\section{RESULTS}

\section{HABITAT MAPPING}

Point (e.g. a spring), polyline (e.g. a drainage ditch) and polygon (e.g. a grassland patch) data were mapped as per the guidelines and because they may all influence grazer behaviour. Fourteen and fifteen habitats were identified in the study area following the Irish and UK classifications, respectively (Table 3). Both totals included two habitat combinations, that is, wet heath or blanket bog with semi-natural dry-humid acid grassland (Irish classification), because in these cases, characteristics of both habitats were exhibited (e.g. an intricate mosaic or a transition between habitats as a consequence of management practices). In this study, we found the UK and Irish classifications 


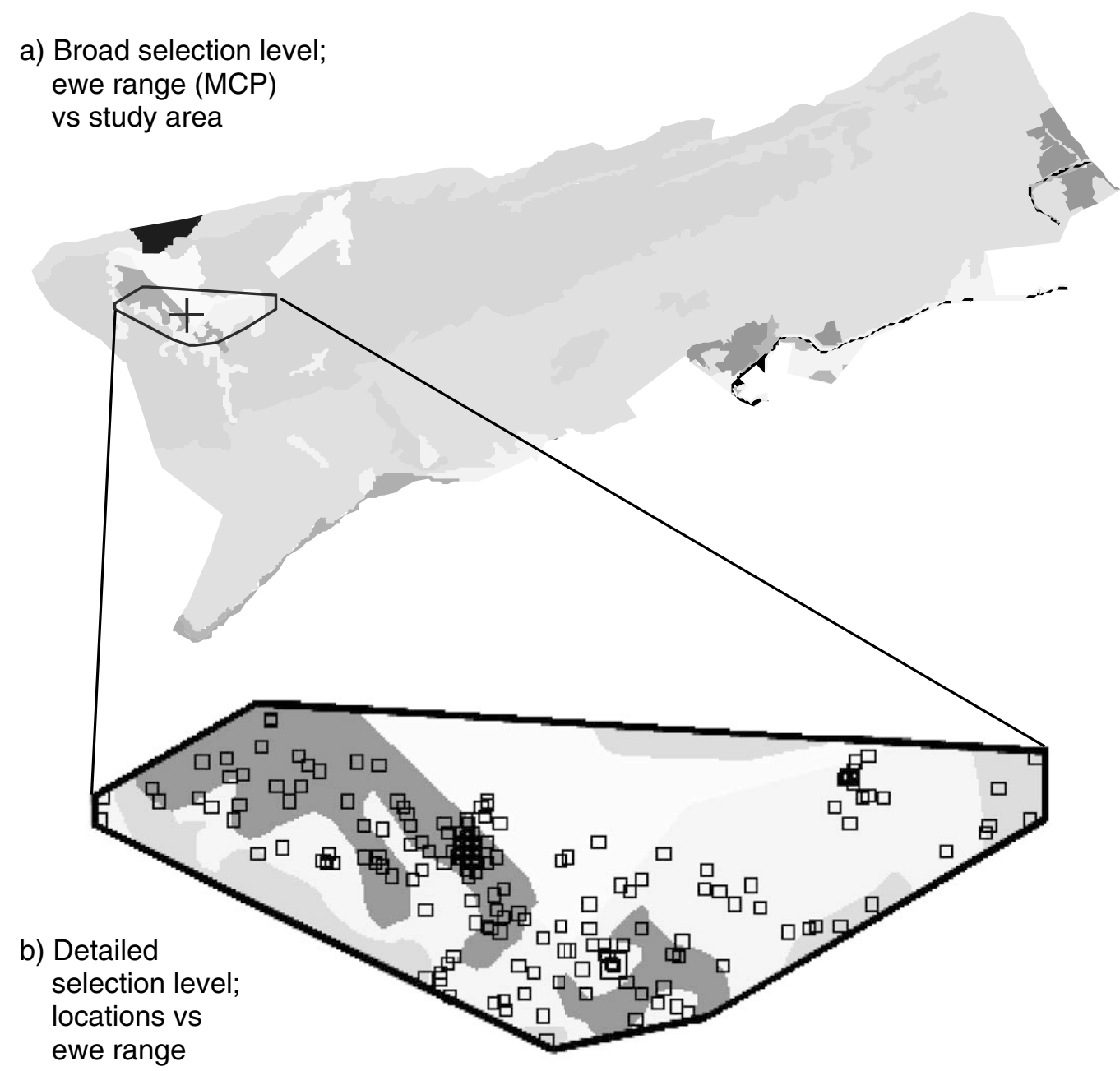

Fig. 2-The two-stage approach used in resource selection analysis.

to be similar with slightly different habitat names, different habitat codes and more bog categories in the latter (Table 3). Hereafter, habitats are referred to following the Irish classification using abbreviations (Table 4). Only polygon data are suitable for compositional analysis and there were eleven polygon habitats accessible to sheep (Table 4; Fig. 3a). Blanket bog and wet heath were the dominant habitats, accounting for $88.1 \%$ of the study area. The third-most available habitat was acid grassland which was representative of just $3.0 \%$ of the area.

Table 2-Composition of seasonal datasets.

\begin{tabular}{lccc}
\hline Dataset & $\begin{array}{c}\text { Ewe ranges } \\
\text { (no.) }\end{array}$ & $\begin{array}{c}\text { Individuals } \\
\text { (no.) }\end{array}$ & $\begin{array}{c}\text { Years sampled } \\
\text { (no.) }\end{array}$ \\
\hline Spring & 9 & 8 & 3 \\
Summer & 7 & 4 & 2 \\
Autumn & 6 & 3 & 2 \\
Winter & 6 & 3 & 2 \\
\hline
\end{tabular}

\section{TRACKING EWES}

The nine individuals mostly occupied the northwest quarter of the study area and were most settled here (Fig. 3b). While there is some ewe range overlap, no two ewe ranges were identical. Range size estimates are discussed by Williams (2011). Visual examination of ewe location data against the habitat map suggested that all ewe ranges were associated with wet heath and acid grassland-related habitats while use of blanket bog was relatively low. The location data enabled range analysis and habitat use analysis, which could then be used in habitat selection analyses.

\section{HABITAT SELECTION}

Proportions of habitats used were compared with those available in the habitat selection analyses. An overview of the proportions of habitats available to and used by tracked ewes is graphically presented in Fig. 4. 
Table 3-Habitats mapped in the study area in 2005. Corresponding Irish and UK classification codes and names are parallel with habitats shown in italics if repeated (i.e. if it corresponds to more than one habitat in the opposing classification).

Habitat code and name

\begin{tabular}{|c|c|c|c|}
\hline \multicolumn{2}{|c|}{$\begin{array}{l}\text { Heritage Council classification } \\
\text { (Ireland) }\end{array}$} & \multicolumn{2}{|c|}{$\begin{array}{c}\text { Joint Nature Conservation Committee } \\
\text { classification (UK) }\end{array}$} \\
\hline \multicolumn{4}{|l|}{ Point data } \\
\hline FP2 & Non-calcareous springs & E2.1 & Acid/neutral flush/spring \\
\hline \multicolumn{4}{|l|}{ Polyline data } \\
\hline FW4 & Drainage ditches & G1.4 & Dystrophic standing open water \\
\hline BL1 & Stone walls and other stone work & $\mathrm{J} 2.5$ & Wall \\
\hline $\mathrm{N} / \mathrm{A}$ & & $\mathrm{J} 2.4$ & Fence \\
\hline \multicolumn{4}{|l|}{ Polygon data } \\
\hline GS3 & $\begin{array}{l}\text { Semi-natural dry-humid acid } \\
\text { grassland }\end{array}$ & B1.2 & Semi-improved acid grassland \\
\hline GS4 & Semi-natural wet grassland & B5 & Marsh/marshy grassland \\
\hline $\mathrm{HH} 3$ & Wet heath & D2 & Wet dwarf shrub heath \\
\hline HH3-GS3 & $\begin{array}{l}\text { Wet heath-Semi-natural dry-humid } \\
\text { acid grassland }\end{array}$ & D2-B1.2 & $\begin{array}{l}\text { Wet dwarf shrub heath- } \\
\text { Semi-improved acid grassland }\end{array}$ \\
\hline HD1 & Dense bracken & C1.1 & Continuous bracken \\
\hline PB3 & Blanket bog ${ }^{\mathrm{a}}$ & E1.7 & Wet modified bog \\
\hline PB3-GS3 & $\begin{array}{l}\text { Blanket bog-Semi-natural } \\
\text { dry-humid acid grassland }\end{array}$ & E1.7-B1.2 & $\begin{array}{l}\text { Wet modified bog-Semi- } \\
\text { improved acid grassland }\end{array}$ \\
\hline PB4 & Cutover bog & E1.7 & Wet modified bog \\
\hline PB5 & Eroding blanket bog & E4 & Bare peat \\
\hline BL2 & Earth banks & $\mathrm{J} 2.8$ & Earth bank \\
\hline BL3 & Buildings and artificial surfaces & $\mathrm{J} 3.6$ & Buildings \\
\hline$B L 3$ & Buildings and artificial surfaces & $\mathrm{J} 5$ & Other habitat (track) \\
\hline
\end{tabular}

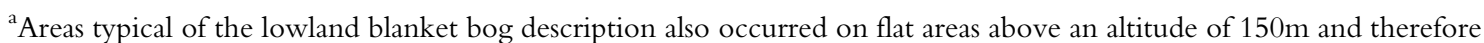
are referred to here as 'blanket bog' without the distinction between upland and lowland (J. Fossitt, pers. comm.).

Earth banks, wet grassland, cutover bog and track were omitted from the dataset at the broad selection level because too many zero values, indicating low use, prohibited compositional analysis. This left seven habitats (blanket bog, wet heath, acid grassland, heath-grassland, bracken, bog-grassland and eroding bog), which were used in analyses for the remaining datasets at the broad level for consistency and to simplify comparisons.

To overcome the problem of too many zero values in compositional analysis at the detailed selection level, two available options were to include only the three most used habitats, or to merge all habitats into a maximum of three groups. Both options were evaluated (Table $5 \mathrm{~b}, \mathrm{~d}$ respectively) and the latter repeated at the broad selection level to enable comparison (Table $5 \mathrm{c}$ ). The eleven polygon habitats were merged into three habitat groups: heath, bog and grassland (Table 4). Where the two habitat combinations (e.g. "wet heath-acid grassland') overlapped two habitat groups (e.g. 'heath' and 'grassland'), values were divided equally between the two groups.

Compositional analysis findings are presented for Complete, Diurnal and Nocturnal Ewe Ranges at broad and detailed selection levels (Table 5). The $\Lambda$ test indicates the overall departure from random use of the available habitats. Habitat selection was significant $(P<0.05)$ for only one of the three datasets presented at the broad selection level with seven habitats and subsequently with three habitat groups (Complete and Diurnal datasets respectively; Table $5 \mathrm{a}, \mathrm{c})$ but significant $(P<0.05)$ for all three datasets at the detailed selection level with three habitats and three habitat groups (Table $5 b, d$ ). Results were inconsistent as some findings indicated that habitat selection was exhibited while others suggested that habitat use was random. Nevertheless, a comparison of results for tests across all datasets (including those not presented) indicated that most $(82 \%)$ of the non-significant $(P>0.05)$ tests produced habitat rank sequences that matched 
Table 4-Polygon habitats accessible to the sheep, listed in order of decreasing area.

\begin{tabular}{llrrl}
\hline $\begin{array}{l}\text { Habitat (Irish Heritage } \\
\text { Council name) }\end{array}$ & \multicolumn{1}{c}{$\begin{array}{c}\text { Abbreviated } \\
\text { habitat name }\end{array}$} & Area (ha) & Area (\%) & Habitat group(s) \\
\hline Blanket bog & blanket bog & 114.5 & 52.8 & Bog \\
Wet heath & wet heath & 76.4 & 35.3 & Heath \\
Semi-natural dry-humid acid grassland & acid grassland & 6.6 & 3.0 & Grassland \\
Wet heath-Semi-natural & heath-grassland & 5.1 & 2.4 & Heath and grassland \\
$\quad$ dry-humid acid grassland & cutover bog & 4.3 & 2.0 & Bog \\
Cutover bog & bracken & 3.4 & 1.6 & Grassland \\
Dense bracken & bog-grassland & 3.4 & 1.6 & Bog and grassland \\
Blanket bog-Semi-natural & & & & \\
$\quad$ dry-humid acid grassland & eroding bog & 1.1 & 0.5 & Bog \\
Eroding blanket bog & wet grassland & 1.0 & 0.5 & Grassland \\
Semi-natural wet grassland & track & 0.8 & 0.4 & Grassland \\
Buildings and artificial surfaces & earth banks & 0.2 & 0.1 & Grassland \\
Earth banks & & $\mathbf{2 1 6 . 9}$ & $\mathbf{1 0 0 . 0}$ & \\
Total & & & & \\
\hline
\end{tabular}

those of at least one significant corresponding test suggesting that ranking sequences were still meaningful. The few remaining non-significant tests had only minor differences with the order of adjacently ranked habitats reversed.

Wet heath and acid grassland habitats were selected most at the broad level and acid grassland was selected most at the detailed level. At both levels, blanket bog was consistently selected least. This general trend was found across all analyses including the three main datasets (Complete, Stable and Fixed-time) and the diurnal and nocturnal subdivisions for each.

\section{Seasonal habitat selection analysis}

Too many zero values limited compositional analyses to six habitats at the broad level in this instance and three habitats at the detailed level as before. The three habitat groups were repeated for consistency. Habitat selection was significant $(P<0.05)$ for $50 \%$ of tests at the broad selection level and for all tests at the detailed selection level (Table 6).

Habitat selection rankings differed considerably between seasons at the broad level with six habitats (Table 6a). Acid grassland was selected most in spring and autumn, wet heath-acid grassland was selected most in summer and wet heath was selected most in winter. Blanket bog and eroding bog were selected least except in summer when eroding bog was second-most selected.

At the detailed selection level for all seasons, acid grassland was selected most with three habitats (Table 6b) and grassland selected most with three habitat groups (Table 6d). The bog habitat group was selected least across all seasons at the broad and detailed levels (Table 6c, d).

\section{DISCUSSION}

\section{HABITAT AVAILABILITY}

The proportional occurrence of the three most abundant habitats, blanket bog, wet heath and acid grassland, was consistent with other upland areas studied in the west of Ireland (Guinan 2005) and plant communities surveyed in the region (Doyle 1982; Bleasdale and Sheehy Skeffington 1992).

\section{SPATIAL DISTRIBUTION OF EWES}

In this study, individual ewe ranges were spatiotemporally independent which, combined with simultaneous field observations of the flock, suggested that collared ewes were members of separate social groups. Scottish Blackface flocks are known to separate into groups (Hewson and Wilson 1979). Therefore it can be argued that the habitat selection findings were representative of the flock as was found to be the case in a concurrent study (Williams et al. 2010).

The most striking feature of the spatial distribution of ewe ranges is that all individuals were most settled in the northwest quarter of the study area. The most likely explanation for this clustering of ewe ranges is that most of the acid grassland was located here. This is almost certainly a product of heavy grazing in the past and where environmental conditions were most conducive to the formation of acid grassland. There were island-like patches of acid grassland scattered across the rest of the study site, which were also selected by sheep. It is unlikely that this spatial pattern is related to sheep choosing exposed altitudes to avoid flies or biting insects as suggested by Warren and Mysterud 

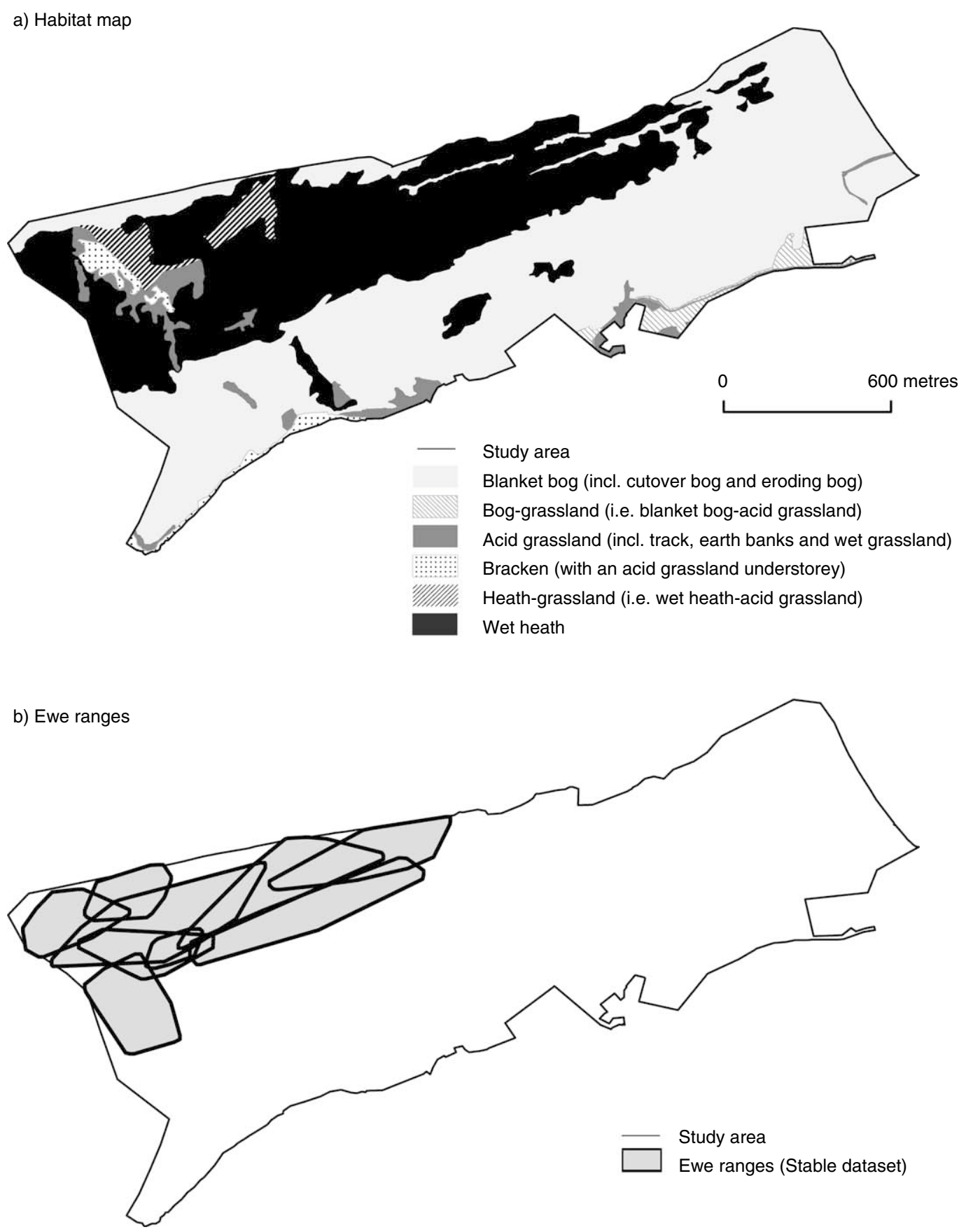

Fig. 3- Spatial patterns of (a) habitat availability and (b) corresponding habitat use by nine Scottish Blackface ewes tracked using Global Positioning System collars. The habitat map displays polygon data with eleven habitats grouped into six categories for presentation purposes. Ewe ranges were estimated using Minimum Convex Polygons (MCPs) and the dataset that represents where ewes were most settled ('Stable dataset') is presented.

(1991) as the majority of locations were within two sheltered bowl-like features and are not at the highest altitude. The distribution pattern in this study bears little or no spatial relationship with livestock management facilities, such as drinking water points, contrasting to findings by Putfarken et al. (2008). In an environment with such high rainfall and strong winds for much of the year, one would expect shelter to be an important factor but even the abovementioned bowl-like features offer poor shelter here in bad weather. Instead, a combination of factors - less peaty soil, steep slopes, better natural drainage, a southerly aspect and the section of the study area probably least impacted by adjacent mountains to the south shading out direct sunlight — contributes to a relatively 'dry lie' 


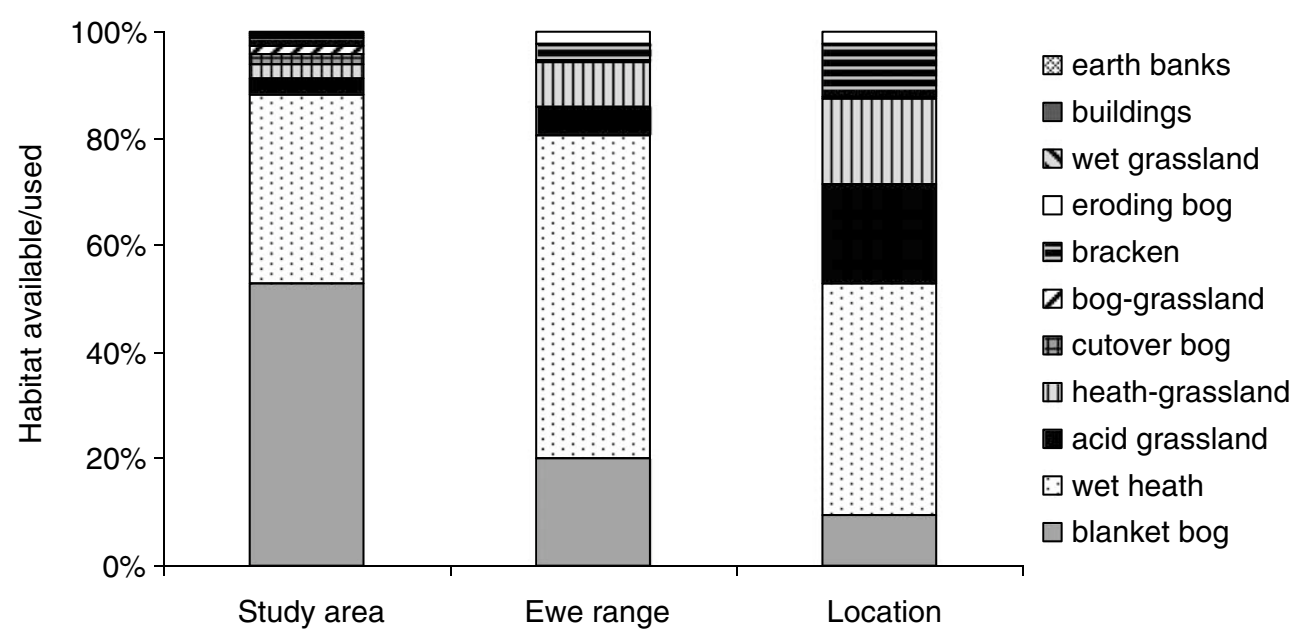

Fig. 4-The proportion of habitats; available in the study area, used/available within ewe ranges (estimated using Minimum Convex Polygons, MCPs), and used at location. The latter two are based on averages for the nine Complete Ewe Ranges dataset.

for sheep and presumably better growth of more palatable forage species.

\section{HABITAT SELECTION}

Acid grassland was consistently the most selected habitat at the detailed selection level (Tables 5 and 6). That is, it was used most relative the proportion available. This has implications for the conservation management of the dominant habitats, which are of international importance, because grazer-related damage was evident particularly where livestock traversed the slope between larger patches of this preferred habitat. By definition, acid grassland can have short dense swards and be a product of heavy grazing (Fossitt 2000) so selection by sheep is not surprising. Other authors also reported a preference of hill sheep for grassland patches (Hunter 1962; Welch 1984; Clarke et al. 1995). Grazers congregate and produce grassland patches where vegetation productivity potential is high and disperse from areas where potential is low (McNaughton 1984). Doyle (1979) reported that new growth of grassland encouraged by cutting or grazing provided sheep diets with a higher protein and energy concentration, and Doyle (1982) suggested that plant biomass was highest on short swards $(\leq 5 \mathrm{~cm}$ above ground level) in blanket bog areas. Hodgson et al. (1991) reported higher digestibility and herbage intake on acid grassland than blanket bog and heath. In summary, acid grassland is selected most probably because of relatively better forage quality and availability compared with other hill habitats. Dense bracken (Pteridium aquilinum) scored a relatively high habitat ranking in this study, probably because it always had an understorey of acid grassland.

Blanket bog may have been selected least (i.e. avoided) for a variety of reasons. The vegetation has low productivity (Doyle 1982), is deficient in minerals (Van Eck et al. 1984) and has the lowest digestibility of all hill communities (Hodgson et al. 1991). The vegetation is also taller which sheep find more difficult to graze and their ability to select is reduced (Grant et al. 1985). This creates a feedback loop where tall vegetation is avoided and dead material accumulates, making the sward increasingly unattractive to sheep and difficult to traverse. Additional features associated with blanket bog that make it difficult for sheep to move through include bog pools, surface water, drainage ditches and areas of quaking peat.

In contrast to the detailed level, wet heath-acid grassland and wet heath were often selected over acid grassland at the broad level. This trend was repeated with the habitat groups. This is probably attributable to patch fragmentation and underrepresentation of acid grassland particularly at the broad selection level because many patches were too small to map and sheep are known to forage while travelling between preferred patches (Clarke et al. 1995). Therefore sheep behaviour is likely to be affected by fragmentation/connectivity between preferred patches, and more detailed information on acid grassland patch frequency could be useful.

Wet grassland, cutover bog, earth banks and track were omitted from some analyses because of low use. Wet grassland and cutover bog are waterlogged for much of the year so access is hindered and palatable plant availability is low. The low use of earth banks and the track is thought to be explained by small patch size limiting resource availability to social groups. Environmental factors such as waterlogging, topography and altitude (not included in analyses for this study) are likely to influence sheep behaviour but, as habitat classification includes these, this limitation is expected to 
Table 5-Tests for random habitat use by nine Scottish Blackface hill sheep at broad and detailed selection levels. 'Complete Ewe Ranges' combines Diurnal and Nocturnal data. The habitat ranking is shown in parentheses when $\Lambda$ is not significant and ' $>>>$ ' denotes a significant difference between two consecutively ranked habitats.

\begin{tabular}{|c|c|c|c|c|c|}
\hline \multirow[t]{2}{*}{ Dataset } & \multicolumn{2}{|c|}{ Randomness test } & \multirow[t]{2}{*}{ Habitat rankings (most $>$ least selected) } & \multirow[t]{2}{*}{ No. of locations } & \multirow[t]{2}{*}{$\%$ of total locations } \\
\hline & $\Lambda$ & $P$ & & & \\
\hline
\end{tabular}

(a) Broad selection level ( $M C P^{a}$ vs. study area) with seven habitats

Complete Ewe Ranges $\quad 0.129 \quad 0.095$

(Heath-grassland $>$ wet heath $>$ acid grassland $>$ bracken $>\quad 21,114$

Diurnal Ewe Ranges $\quad 0.043 \quad 0.046^{\star}$

eroding bog $>$ blanket bog $>>>$ bog-grassland)

Nocturnal Ewe Ranges $\quad 0.060 \quad 0.054$

Heath-grassland $>$ wet heath $>$ acid grassland $>$ bracken $>\quad 10,998$

99.6

eroding bog $>$ blanket bog $>>>$ bog-grassland

(Heath-grassland $>$ acid grassland $>$ wet heath $>$ bracken $>\quad 10,138$

eroding bog $>$ blanket bog $>$ bog-grassland)

(b) Detailed selection level (locations vs. MCP) with three habitats

$\begin{array}{lll}\text { Complete Ewe Ranges } & 0.091 & 0.005 \star \star \\ \text { Diurnal Ewe Ranges } & 0.050 & 0.006 \star \star \\ \text { Nocturnal Ewe Ranges } & 0.140 & 0.009 \star \star\end{array}$

Acid grassland $>>>$ heath-grassland $>$ wet heath

Acid grassland $>>>$ heath-grassland $>$ wet heath

$0.009 \star \star$

Acid grassland $>>>$ heath-grassland $>$ wet heath

$\begin{array}{rr}16,731 & 77.8 \\ 8672 & 79.1 \\ 8066 & 77.0\end{array}$

(c) Broad selection level (MCP vs. study area) with three habitat groups

$\begin{array}{lllll}\text { Complete Ewe Ranges } & 0.455 & 0.048^{\star} & \text { Heath }>\text { grassland }>>>\text { bog } & 21,250 \\ \text { Diurnal Ewe Ranges } & 0.471 & 0.089 & \text { (Heath }>\text { grassland }>>>\text { bog) } & 100.0 \\ \text { Nocturnal Ewe Ranges } & 0.493 & 0.069 & \text { (Heath }>\text { grassland }>>>\text { bog) } & 11,073\end{array}$

(d) Detailed selection level (locations vs. MCP) with three habitat groups

\begin{tabular}{lllll} 
Complete Ewe Ranges & 0.172 & $0.007^{\star \star}$ & Grassland $>>>$ heath $>>>$ bog & 21,250 \\
Diurnal Ewe Ranges & 0.244 & $0.028^{\star}$ & Grassland $>>>$ heath $>>>$ bog & 100.0 \\
Nocturnal Ewe Ranges & 0.216 & $0.008^{\star \star}$ & Grassland $>>>$ heath $>>>$ bog & 11,073 \\
\hline
\end{tabular}

${ }^{\mathrm{a}} \mathrm{MCP}=$ Minimum Convex Polygon, used to estimate ewe ranges. ${ }^{*} P<0.05, \star \star P P 0.01$. 
Table 6-Tests for seasonal random habitat use by Scottish Blackface hill sheep at broad and detailed selection levels, using 28 ewe ranges in total. The habitat ranking is shown in parentheses when $\Lambda$ is not significant and ' $>>>$ ' denotes a significant difference between two consecutively ranked habitats.

$\begin{array}{cccc}\text { Dataset } & \text { Randomness test } & \text { Habitat rankings (most }>\text { least selected) } & \text { No. of locations }\end{array}$

(a) Broad selection level (MCPa vs. study area) with six habitats

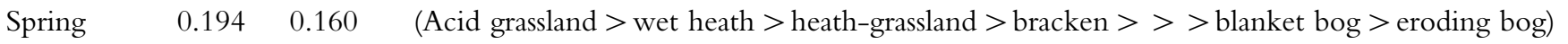

Summer $0.015 \quad 0.046^{\star} \quad$ Heath-grassland $>$ eroding bog $>$ bracken $>$ acid grassland $>$ wet heath $>>>$ blanket bog

Winter $\quad 0.165 \quad 0.532 \quad$ (Wet heath $>$ heath-grassland $>$ acid grassland $>$ bracken $>$ blanket bog $>$ eroding bog)

(b) Detailed selection level (locations vs. MCP) with three habitats

Spring $\quad 0.116 \quad 0.003 \star \star$ Acid grassland $>>>$ heath-grassland $>$ wet heath

$\begin{array}{llll}\text { Summer } & 0.050 & 0.019^{\star} & \text { Acid grassland }>\text { heath-grassland }>>>\text { wet heath }\end{array}$

Autumn $\quad 0.030 \quad 0.035^{\star} \quad$ Acid grassland $>>>$ wet heath $>$ heath-grassland

Winter $0.014 \quad 0.046^{\star}$ Acid grassland $>>>$ wet heath $>$ heath-grassland

(c) Broad selection level (MCP vs. study area) with three habitat groups

$\begin{array}{llll}\text { Spring } & 0.478 & 0.111 & \text { (Heath }>\text { grassland }>>>\text { bog) }\end{array}$

Summer $\quad 0.222 \quad 0.021 \star \quad$ Grassland $>$ heath $>>>$ bog

Autumn $\quad 0.201 \quad 0.028^{\star} \quad$ Grassland $>>>$ heath $>$ bog

Winter $\quad 0.157 \quad 0.034^{\star} \quad$ Heath $>$ grassland $>$ bog

(d) Detailed selection level (locations vs. MCP) with three habitat groups

Spring $\quad 0.153 \quad 0.006^{\star \star}$ Grassland $>>>$ heath $>>>$ bog

Summer $\begin{array}{llll}0.038 & 0.019 \star & \text { Grassland }>>>\text { heath }>\text { bog }\end{array}$

Autumn $\quad 0.022 \quad 0.035^{\star} \quad$ Grassland $>>>$ heath $>$ bog

17,359
15,070

Winter

$$
0.117 \quad 0.025^{\star} \quad \text { Grassland }>>>\text { heath }>\text { bog }
$$

${ }^{\mathrm{a}} \mathrm{MCP}=$ Minimum Convex Polygon, used to estimate ewe ranges. ${ }^{\star} P<0.05,{ }^{\star}{ } P<0.01$. 
be generally applicable in similar habitat selection studies. However, spatial properties such as patch size and proximity to favoured patches could influence results from different study areas and require further investigation.

Almost identical habitat rankings were found when diurnal and nocturnal locations were compared, and detailed selection results suggest that Scottish Blackface sheep selected acid grassland most for grazing and resting, day and night. This contrasts with findings by Bakker et al. (1983) and Hewson and Wilson (1979) who, using direct observations, reported that sheep occupied different habitats at night compared with daytime use. Probable explanations for these inconsistencies include different habitat assemblages studied by the above authors and the fact that nocturnal locations in this study included twilight movement.

Given that the results of this study reflect those using direct animal observations, the use of GPS collars for grazing resource selection studies in heterogeneous hill environments is highly recommended because they (1) minimize human disturbance, (2) provide higher recording frequencies and numbers of records, (3) have increased location accuracy, (4) record day and night in all weather conditions, (5) minimize the effect of complex topography that can obscure observer view, (6) economize on labour input for data collection and (7) are devoid of recorder bias.

\section{Seasonal habitat selection}

Seasonal variation in habitat rankings was evident despite being based on only a small number of individuals. This was not surprising as seasonal variation is reported in both plant palatability and hill sheep diets (Bullock 1985; Grant et al. 1987). Habitat selection rankings of the Complete dataset (Table 5) were most closely associated with those for spring from seasonal tests at both selection levels (Table 6). This may have been due to the low availability of the core ewes during spring. However, seasonal variation in habitat selection was evident and deserves consideration in grazing management.

\section{IMPLICATIONS FOR CONSERVATION}

Rowell and Clarke (1988) recognized that the proportion of each plant community available is an important factor in setting stocking levels where animals range freely across an area that includes peatland. This study's findings of uneven sheep use of the hill resource are consistent with findings by others (Hunter 1962; Hewson and Wilson 1979; Rutter et al. 1997). These findings support an argument by some ecologists that there is a need for change from management prescriptions based on simple stocking density to prescriptions that explicitly consider the habitat availability and spatial distribution of grazers (Hester and Baillie 1998).

Suitable stocking rates are likely to need complementary alternative grazing measures to realize sustainable management of uplands and peatlands. Management recommendations for hill areas have included controlling grazing through housing sheep over winter (Bleasdale 1998), fencing to control summer and winter grazing levels (Hunter 1962) and grazing goats or cattle with sheep (Hunter 1962; Celaya et al. 2007). However, excluding sheep from blanket bog areas should not be necessary to meet conservation objectives, provided the sites are not overstocked and alternative habitats are available with selection rankings that are higher than that for blanket bog. Reductions in stocking densities would probably have most impact on arresting grazing-related damage on hill areas that support very low proportions of habitats most preferred by grazers.

The finding that blanket bog habitats were consistently selected least suggests stocking rate calculations should omit areas of available blanket bog where alternative, preferred habitats are available. Grazers may use blanket bog to access preferred patches in a mosaic of habitats that are less susceptible to damage, thus highlighting the need to know which habitats occur and how the habitats are distributed, and to study habitat selection on a greater number of sites. Results from these new GPS data (1) corroborate the findings of previous work on plant community/habitat selection and (2) provide additional information that can be used to strengthen existing or new hill grazing management models (used to aid decision-making). Further research is recommended on seasonal habitat selection by different grazing animals and breeds, in different habitat assemblages and with larger sample sizes. The findings have potential practical application and emphasize the importance of collecting habitat selection information in achieving appropriate grazing management in complex landscapes.

The success of achieving habitat conservation objectives is dependent on agri-environment policies and schemes that heavily influence the economic viability of extensive farming systems and consequently farmer management decisions. If environmental issues such as overgrazing and undergrazing of uplands and peatlands are to be resolved, agri-environment schemes need to include measures to monitor habitat condition (as is currently practiced under the Rural Environment Protection Scheme and NPWS Commonage Framework in Ireland) combined with resource selection by grazers, and to implement site level management plans. Habitats should be mapped on sites containing upland and peatland and stocking rates should be 
calculated based on areas of available habitats, as per Dúchas (1999) but omitting the area of habitats that are consistently avoided by sheep. Potential travel routes between favourable habitat patches should also be taken into consideration.

\section{ACKNOWLEDGEMENTS}

Thanks to Teagasc for funding this research under the Walsh Fellowship Scheme, and the following for their assistance; Luke O’Malley, P.J. Hastings, J.P. Hanrahan, Rod Green, John Warren, James Moran, Juan Carlos Castaneda, Stephen Kelly, Micheline Sheehy Skeffington, Julie Fossitt, Andy Bleasdale, Heather Lally, Niamh Quinn and two anonymous reviewers.

\section{REFERENCES}

Aebischer, N.J., Robertson, P.A. and Kenward, R.E. 1993 Compositional analysis of habitat use from animal radio-tracking data. Ecology 74, 1313-25.

Agreil, C., Fritz, H. and Meuret, M. 2005 Maintenance of daily intake through bite mass diversity adjustment in sheep grazing on heterogeneous and variable vegetation. Applied Animal Behaviour Science 91, 35-56.

Armstrong, H.M., Gordon, I.J., Hutchings, N.J., Illius, A.W., Milne, J.A. and Sibbald, A.R. 1997 A model of the grazing of hill vegetation by sheep in the UK. II. The prediction of offtake by sheep. Journal of Applied Ecology 34, 186-207.

Bakker, J.P., de Bie, S., Dallinga, J.H., Tjaden, P. and de Vries, Y. 1983 Sheep-grazing as a management tool for heathland conservation and regeneration in the Netherlands. Journal of Applied Ecology 20, 541-60.

Bertiller, M.B. and Ares, J.O. 2008 Sheep spatial grazing strategies at the arid Patagonian Monte, Argentina. Rangeland Ecology and Management 61, $38-47$.

Bleasdale, A. 1998 Overgrazing in the west of Ireland/—assessing solutions. In G. O'Leary and F. Gormley (eds), Towards a conservation strategy for the bogs of Ireland, 67-78. Dublin. Irish Peatland Conservation Council.

Bleasdale, A. and Sheehy Skeffington, M. 1992 The influence of agricultural practices on plant communities in Connemara. In J. Feehan (ed), Environment and development in Ireland, 331-6. Dublin. University College Dublin.

Brigand, L. and Bioret, F. 1994 Réflexions sur l'influence du mouton dans les modes de gestion des milieux insulaires: Ouessant (Bretagne-France) et Clare Island (Mayo-Irlande). Norois 41, 559-64.

Bullock, D.J. 1985 Annual diets of hill sheep and feral goats in southern Scotland. Journal of Applied Ecology 22, 423-33.

Cadbury, C.J. 1987 Moorland birds-Britain's international responsibility. In C.J. Cadbury and
M. Everett (eds), RSPB conservation review 1987, 59-64. Sandy. Royal Society for the Protection of Birds.

Celaya, R., Oliván, M., Ferreira, L.M.M., Martínez, A., García, U. and Osoro, K. 2007 Comparison of grazing behaviour, dietary overlap and performance in non-lactating domestic ruminants grazing on marginal heathland areas. Livestock Science 106, 271-81.

Clarke, J.L., Welch, D. and Gordon, I.J. 1995 The influence of vegetation pattern on the grazing of heather moorland by red deer and sheep. I. The location of animals on grass/heather mosaics. Journal of Applied Ecology 32, 166-76.

D'Eon, R.G. and Delparte, D. 2005 Effects of radiocollar position and orientation on GPS radio-collar performance, and the implications of PDOP in data screening. Journal of Applied Ecology 42, 383-8.

Davidson-Watts, I., Walls, S. and Jones, G. 2006 Differential habitat selection by Pipistrellus pipistrellus and Pipistrellus pygmaeus identifies distinct conservation needs for cryptic species of echolocating bats. Biological Conservation 133, 118-27.

Department of Arts Heritage Gaeltacht and the Islands 2002 National biodiversity plan. Dublin. Government of Ireland.

Doyle, J.J. 1979 The effect of nitrogen, phosphorus and potassium fertilization on chemical content of sheep diets. Journal of Range Management 32, $162-3$.

Doyle, G.J. 1982 The vegetation, ecology and productivity of Atlantic blanket bog in Mayo and Galway, western Ireland. Journal of Life Sciences Royal Dublin Society 3, 147-64.

Dúchas the Heritage Service and the Department of Agriculture and Food 1999 A manual for the production of grazing impact assessments in upland and peatland habitats. Dublin. Dúchas the Heritage Service \& the Department of Agriculture and Food.

European Commission 2008 EU nature legislation Available at ec.europa.eu/environment/nature/ legislation/index_en.htm (last accessed 1 January 2010).

European Environmental Advisory Councils 1999 Annex: agriculture and environment in eight European countries Available at www.eeac-net.org/workgroups/ pdf/WGAgriculture_Agenda200_Proposals_1999_ Annex.pdf (last accessed 1 January 2010).

Fenton, E.W. 1937 The influence of sheep on the vegetation of hill grazings in Scotland. Journal of Ecology 25, 424-30.

Fossitt, J.A. 2000 A guide to habitats in Ireland. Kilkenny. The Heritage Council.

Fraser, M.D., Theobald, V.J., Griffiths, J.B., Morris, S.M. and Moorby, J.M. 2009 Comparative diet selection by cattle and sheep grazing two contrasting heathland communities. Agriculture, Ecosystems and Environment 129, 182-92.

Gardiner, M.J. and Radford, T. 1980 Soil associations of Ireland and their land use potential. Soil Survey Bulletin no. 36. Dublin. An Foras Talúntais.

Ginane, C. and Dumont, B. 2006 Generalization of conditioned food aversions in grazing sheep and its implications for food categorization. Behavioural Processes 73, 178-86. 
Grant, S.A., Suckling, D.E., Smith, H.K., Torvell, L., Forbes, T.D.A. and Hodgson, J. 1985 Comparative studies of diet selection by sheep and cattle: the hill grasslands. Journal of Ecology 73, 987-1004.

Grant, S.A., Torvell, L., Smith, H.K., Suckling, D.E., Forbes, T.D.A. and Hodgson, J. 1987 Comparative studies of diet selection by sheep and cattle: blanket bog and heather moor. Journal of Ecology 75, 947-60.

Guinan, L.M. 2005 Studies investigating the physical degradation of selected Irish hillsides: plantherbivore interactions, digital photogrammetry and climate. Unpublished PhD thesis, University College Dublin, Dublin.

Heady, H.F. 1964 Palatability of herbage and animal preference. Journal of Range Management 17, 76-82.

Heritage Council 2002 Habitat survey guidelines: a standard methodology for habitat survey and mapping in Ireland-draft. Kilkenny. The Heritage Council.

Hester, A.J. and Baillie, G.J. 1998 Spatial and temporal patterns of heather use by sheep and red deer within natural heather/grass mosaics. Journal of Applied Ecology 35, 772-84.

Hester, A.J., Gordon, I.J., Baillie, G.J. and Tappin, E. 1999 Foraging behaviour of sheep and red deer within natural heather/grass mosaics. Journal of Applied Ecology 36, 133-46.

Hewson, R. and Wilson, C.J. 1979 Home range and movements of Scottish Blackface sheep in Lochaber, north-west Scotland. Journal of Applied Ecology 16, 743-51.

Hodgson, J., Forbes, T.D.A., Armstrong, R.H., Beattie, M.M. and Hunter, E.A. 1991 Comparative studies of the ingestive behaviour and herbage intake of sheep and cattle grazing indigenous hill plant communities. Journal of Applied Ecology 28, 205-27.

Holden, J., Shotbolt, L., Bonn, A., Burt, T.P., Chapman, P.J., Dougill, A.J., Fraser, E.D.G., Hubacek, K., Irvine, B., Kirkby, M.J., Reed, M.S., Prell, C., Stagl, S., Stringer, L.C., Turner, A. and Worrall, F. 2007 Environmental change in moorland landscapes. Earth-Science Reviews 82, 75-100.

Hulbert, I.A.R. and French, J. 2001 The accuracy of GPS for wildlife telemetry and habitat mapping. Journal of Applied Ecology 38, 869-78.

Hulbert, I.A.R., Wyllie, J.T.B., Waterhouse, A., French, J. and McNulty, D. 1998 A note on the circadian rhythm and feeding behaviour of sheep fitted with a lightweight GPS collar. Applied Animal Behaviour Science 60, 359-64.

Hunter, R.F. 1962 Hill sheep and their pasture: a study of sheep-grazing in south-east Scotland. Journal of Ecology 50, 651-80.

Johnson, D.H. 1980 The comparison of usage and availability measurements for evaluating resource preference. Ecology 61, 65-71.

Kenward, R.E. 1992 Quantity versus quality: programmed collection and analysis of radio-tracking data. In I.G. Priede and S.M. Swift (eds), Wildlife telemetry: remote monitoring and tracking of animals, 231-46. Chichester. Ellis Horwood.

Kenward, R.E. 2001 A manual for wildlife radio tagging. London. Academic Press.

Kenward, R.E., Clarke, R.T., Hodder, K.H. and Walls, S.S. 2001 Density and linkage estimators of home range: nearest-neighbor clustering defines multinuclear cores. Ecology 82, 1905-20.

Lotek Wireless 2000 N4 differential post-processing software users' manual. Ontario. Lotek Wireless.

Lotek Wireless 2001 Small animal GPS location system: user's manual: GPS 2000 Series. Ontario. Lotek Wireless.

Lotek Wireless 2004 Product sheet: GPS_2200 collar for livestock <www.lotek.com/gps_22001.pdf> [Last accessed January 2010].

Macaulay Institute 2009 Decision support tools to link ecology and land management: Development of HillPlan $<$ www.macaulay.ac.uk/hillplan/ > [Last accessed January 2010].

Manly, B.F.J., McDonald, L.L. and Thomas, D.L. 1993 Resource selection by animals: statistical design and analysis for field studies. London. Chapman and Hall.

McNaughton, S.J. 1984 Grazing lawns: animals in herds, plant form, and coevolution. American Naturalist $\mathbf{1 2 4}, 863-86$.

Met Éireann 2010 Climate of Ireland. Available at www.met.ie/climate/climate-of ireland.asp (last accessed 1 January 2010).

National Parks and Wildlife Service 2005 Farm plan scheme for designated areas and commonages: specifications document. Dublin. The National Parks and Wildlife Service.

National Parks and Wildlife Service 2010 Protected sites. Available at www.npws.ie/en/ProtectedSites (last accessed 1 January 2010).

Nature Conservancy Council 1990 Handbook for Phase 1 habitat survey: a technique for environmental audit. UK. Joint Nature Conservation Committee.

Ordnance Survey Ireland 2012 Active GPS station data. Available at www.osi.ie/Services/ GPS-Services/Active-GPS-Station-Data.aspx (last accessed 1 April 2010).

Putfarken, D., Dengler, J., Lehmann, S. and Härdtle, W. 2008 Site use of grazing cattle and sheep in a large-scale pasture landscape: a GPS/GIS assessment. Applied Animal Behaviour Science 111, 54-67.

Roberts, G., Williams, A., Last, J.D., Penning, P.D. and Rutter, S.M. 1995 A low-power postprocessed DGPS system for logging the locations of sheep on hill pastures. Navigation 42, 327-36.

Rowell, T.A. and Clarke, M.J. 1988 Grazing. In T.A. Rowell (ed), The peatland management handbook: research and survey in nature conservation no. 14, 1-15. Peterborough. Nature Conservancy Council.

Rutter, S.M., Beresford, N.A. and Roberts, G. 1997 Use of GPS to identify the grazing areas of hill sheep. Computers and Electronics in Agriculture 17, 177-88.

Smith, P.G. 2006 Compos analysis version 6.2 user's guide. Abergavenny. Smith Ecology Ltd.

Thomas, B., Holland, J.D. and Minot, E.O. 2008 Elephant (Loxodonta africana) home ranges in Sabi Sand Reserve and Kruger National Park: a five-year satellite tracking study. PLoS ONE 3, e3902.

Thompson, D.B.A., MacDonald, A.J., Marsden, J.H. and Galbraith, C.A. 1995 Upland heather moorland in Great Britain: a review of international importance, vegetation change and some objectives for nature conservation. Biological Conservation 71, 163-78. 
Thomson, A.M. and Simpson, I.A. 2006 A grazing model for simulating the impact of historical land management decisions in sensitive landscapes: model design and validation. Environmental Modelling and Software 21, 1096-113.

Umstätter, C., Waterhouse, A. and Holland, J.P. 2008 An automated sensor-based method of simple behavioural classification of sheep in extensive systems. Computers and Electronics in Agriculture 64, 19-26.

Van Eck, H., Govers, A., Lemaire, A. and Schaminée 1984 Irish bogs: a case for planning. Nijmegen. Katholieke Universiteit.

Wallis De Vries, M.F. and van de Koppel, J. 1998 The role of scientific models. In M.F. Wallis De Vries, J.P. Bakker and S.E. Van Wieren (eds), Grazing and conservation management, 321-47. Dordrecht. Kluwer Academic Publishers.

Walsh, M., Mulqueen, J., Grennan, E., Rogers, M., Marren, N., Guinan, L., Nixon, D. and Collins, J.F. 2000 Evaluation of the impact of livestock on the hill environment. End of Project Reports: Sheep Series no. 10. Project no. 4043. Athenry. Teagasc Agriculture and Food Development Authority.

Warren, J.T. and Mysterud, I. 1991 Summer habitat use and activity patterns of domestic sheep on coniferous forest range in southern Norway. Journal of Range Management 44, 2-6.

Welch, D. 1984 Studies in the grazing of heather moorland in north-east Scotland. I. Site descriptions and patterns of utilization. Journal of Applied Ecology 21, 179-95.

Williams, B., Walsh, M., Gormally, M., Walls, S. and Sheahan, J. 2010 Resource selection by hill sheep: direct flock observations versus GPS tracking. Applied Ecology and Environmental Research 8, 279-300.

Williams, B., Walls, S.S., Gormally, M.J., Walsh, M. and Sheahan, J. 2011 Management considerations fore conserving hill areas highlighted by range analysis of hill sheep. Tearmann: Irish Journal of Agri-environmental Research 8, 59-76. 